\title{
熱硬化型PPE樹脂積層板の高周波領域の 誘電特性の安定性
}

\author{
新井 雄史*, 横山 秀久*, 木下 昌三*, 片寄 照雄 ${ }^{*}$
}

\section{Stability of Dielectric Characteristics of Thermosetting PPE Resin Laminate}

\author{
Takeshi ARAI*, Hidehisa YOKOYAMA*, Shozo KINOSHITA*and Teruo KATAYOSE*
}

\author{
*旭化成工業株式会社製品技術研究所（广210 神奈川県川崎市川崎区夜光1-3-1） \\ *Designed Products Laboratory, Asahi Chemical Industry Co., Ltd. (1-3-1 Yako, Kawasaki-ku, Kawasaki-shi, Kanagawa 210)
}

\begin{abstract}
概要 耐熱性および優れた誘電特性を有するプリント配線板材料として熱硬化型PPE樹脂S4100を開発した。S4100とガラ スクロスを用いて銅張積層板を作成し特性を調べたところ，S4100積層板は $2 \mathrm{GHz}$ における比誘電率が 3.36 , 誘電正接が 0.004 と良好な高周波特性を有し，かつガラス転移温度が $200^{\circ} \mathrm{C}$ とポリイミドに次ぐ高い耐熱性を合わせ持つ材料であることがわか った。材料の絶縁信頼性の尺度の 1 つとて $\mathrm{GHz}$ 領域の誘電特性の安定性が重要であると考え， S4100積層板の誘電率，誘電 正接の温度依存性と加湿条件下での特性変化を調べ, FR-4積層板およびフッ素樹脂積層板と比較した。S4100積層板の誘電率， 誘電正接の温度依存性は小さく，代表的な低誘電率低損失材料であるフッ素樹脂積層板以上の安定性を有していた。プレッシ ヤークッカーによる加湿に対する誘電特性の安定性の評価では, 吸水率が $0.2 \%$ FR-4積層板の $0.9 \%$ 小さいため, 誘電率, 誘電正接の変化が小さかった。この加湿条件ではFR-4積層板にはんだ耐熱試験でふくれが発生したが，S4100積層板には問題 は発生しなかった。伝送損失測定により，0.8 4GHzの周波数領域ではS4100積層板がフッ素樹脂積層板と同等の低伝送損失 であることがわかった。高速デジタル回路板や高周波通信機器の基板などに有用な材料であることが確かめられた。
\end{abstract}

\begin{abstract}
Thermosetting PPE resin S4100 was developed as an insulating material for printed circuit boards, which has both high glass transition temperature and excellent dielectric characteristics. S4100 laminate produced by using E-glass cloth was evaluated and found to have both superior dielectric properties, such as $\varepsilon=3.36, \tan \delta=0.004$ at $2 \mathrm{GHz}$, and high $\mathrm{Tg}$ of $200^{\circ} \mathrm{C}$ which is comparable to polyimide laminate. The dependence of dielectric constant and dissipation factor on temperature, and their stability under humidified condition were evaluated and the results were compared with FR-4 and polytetrafluoroethylene(PTFE) laminate based on the idea that stability of dielectric characteristics at $\mathrm{GHz}$ region is an important measure of insulation reliability of insulating materials. Dielectric characteristics of S4100 laminate were found to be more stable than PTFE laminate having lower dielectric constant and dissipation factor, under temperature change ranging from $-20^{\circ} \mathrm{C}$ to $80^{\circ} \mathrm{C}$ because of high glass transition temperature of S4100 laminate. Furthermore, S4100 laminate showed smaller change in dielectric constant snd dissipation factor under the condition of humidified in pressure vessel because S4100 had low water absorption of $0.2 \%$ by weight. Moreover, S4100 laminate had no blistering in solder bath after the test. On the other hand, FR-4 showed high water absorption of $0.9 \%$ by weight and blistering in solder bath under the above conditions. The measurement of transmission loss of laminate certified the fact that S4100 laminate has very low transmission loss, which is nearly equal to that of PTFE laminates in the frequency range of $0.8 \sim 4 \mathrm{GHz}$. It is confirmed that $\mathrm{S} 4100$ is a useful material for the application to PWB's of high speed digital circuits and high frequency communication equipment.
\end{abstract}

\section{1. まえがき}

ポリフェニレンエーテル（PPE）は，低誘電率（ $\varepsilon_{\mathrm{r}}=$ 2.45）かつ耐熱性（ガラス転移温度 $\mathrm{Tg}=210^{\circ} \mathrm{C}$ ）の樹脂と して知られている。熱可塑性でしかも耐溶剤性に乏しい PPEを熱硬化性にし，プリント配線板材料に用いようとす る試みが行われており，エポキシ樹脂とのポリマーアロイ が実用化されている。この方法によると，エポキシ樹脂積
層板の $\varepsilon_{\mathrm{r}}=4.7 \sim 5.0(1 \mathrm{MHz}), \tan \delta=0.015 \sim 0.019$ $(1 \mathrm{MHz}), \mathrm{Tg}=160^{\circ} \mathrm{C}$ に対し $\varepsilon_{\mathrm{r}}=3.9 \sim 4.3, \tan \delta=0.01 \sim$ $0.015, \mathrm{Tg}=190 \sim 200^{\circ} \mathrm{C}$ と改善されるが，エポキシ樹脂の 特性が色濃く現れ，特に誘電特性はエポキシ樹脂に近いも のになってしまう。われわれは低誘電率（ $\varepsilon_{\mathrm{r}}=3.0 \sim 3.5$; Eガラスクロスを用いた積層板としての值, 以下同様), 低 誘電正接（ $\tan \delta=0.002 \sim 0.003 ）$ かつ耐熱性（ $\mathrm{Tg}=230 \sim$ $250^{\circ} \mathrm{C}$ ）を有する熱硬化型ポリフェニレンエーテル（PPE） 
樹脂を開発し，その物性，多層配線板材料としての加工性 および信頼性についてすでに報告した ${ }^{1), 2)}$ 。今回さらに0.8 〜10GHzの高周波領域の誘電正接を特に小さくすることに 重点を置いて材料設計に検討を加え, 従来最高性能として 知られるフッ素樹脂積層板に匹敵する低伝送損失の熱硬化 型PPE樹脂材料［S4100］を開発したので，これを用いた 銅張積層板の高周波領域の誘電特性とその特性の安定性に ついて報告する。

絶縁材料に信号の高速伝送に有利なように低誘電率が要 求される高速デジタル回路では，マイクロプロセッサの動 作周波数が200MHzを超えるようになったため，材料の誘 電特性はその5次高調波である $1 \mathrm{GHz}$ 以上までが評価の対 象になってきた。 $1 \mathrm{GHz}$ 付近の材料の損失は信号の立ち上 がり立ち下がりの波形のなまりとしてLSIの動作に影響を 与える。携帯電話, 交換機などの通信機器では大容量化, 高速化のため搬送波の周波数が相次いでGHz領域に移行し つつあり, この領域で比較的材料の損失が大きくなって無 視できなくなるために誘電特性が重要な設計パラメータと 考えられるようになった。すなわち，これらの用途におい てはGHz領域の材料の伝送損失が小さいことが必要とな

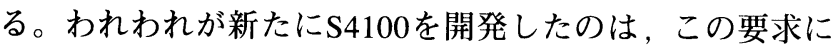
応えるためである。樹脂材料の設計が積層板の伝送損失に 及ぼす影響を検討することにより，開発に成功した。

材料の誘電特性は当然優秀であることが望ましいが, 温 度, 湿度といった変化しやすい外部の要因に対して誘電特 性が変動すると機器の動作に支障を生じる可能性を考慮す る必要がある。著者らは，特にGHz領域で用いられる優秀 な誘電特性が必要とされる絶縁材料に対しては, 誘電特性 の安定性は絶縁信頼性の重要な尺度であると考え, S4100 積層板の GHz領域の誘電特性と, その温度依存性および加 湿条件下での特性変化を, 代表的な配線板材料であるFR-4 積層板およびフッ素樹脂積層板と比較して検討した。

\section{2. 実験}

\section{$2.1 \mathrm{GHz}$ 領域の誘電特性の測定方法}

試料の誘電率は, 被測定積層板により図 1 に示すトリプ レートストリップライン共振器を構成し，共振周波数 $\mathrm{f}_{0}$ と 緑端効果を補正した実効的なストリップ長 L から式 (1) を用いて求められる。縁端効果の補正量は，相異なるス卜 リップ長の 2 組の共振器の共振周波数 $\mathrm{f}_{0}$ の比較から求めた。 誘電正接は同じ共振器を用い, 田中らの損失分離法 ${ }^{3)}$ に従 って共振器の $\mathrm{Q}$ 值から求めた。この方法を用いた理由は, 田中らが銅䈃の電気導電率は銅箔の品質に著しく依存する という結論を得ていることから，銅箔の電気導電率を実験 により決定する本法によらなければ低損失材料の誘電正接 を正確に評価することは困難であると考えたためである。 田中らの損失分離法は高精度であること, プリント配線板 用の積層板をなんら実質的な加工を必要とせず，そのまま
試料に用いることができること等，優れた特徴を有してい る。共振周波数および $\mathrm{Q}$ 值の測定には横河ヒューレッ ト・パッカードのネットワークアナライザHP8510Bシステ ムを用いた。HP8510Bにより直接測定される共振器の共振 特性の例を図 2 に示す。寸法の異なる複数の共振器を用意 し，それぞれについて各共振ピークの共振周波数 $\mathrm{f}_{0}$, 減衰 率 $\alpha$, 共振の半值幅 $\Delta \mathrm{f} / \mathrm{f}_{0}$ を測定すれば損失分離法により 誘電正接を決定することができる。

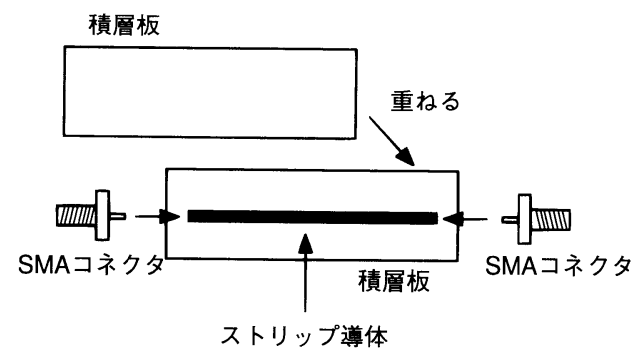

(a)平面図

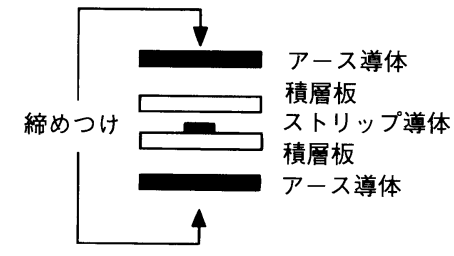

(b)コネクタ方向から見た断面図

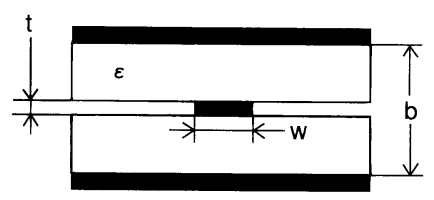

(c)断面各部の寸法記号

図 1 ．ストリップライン共振器の構造

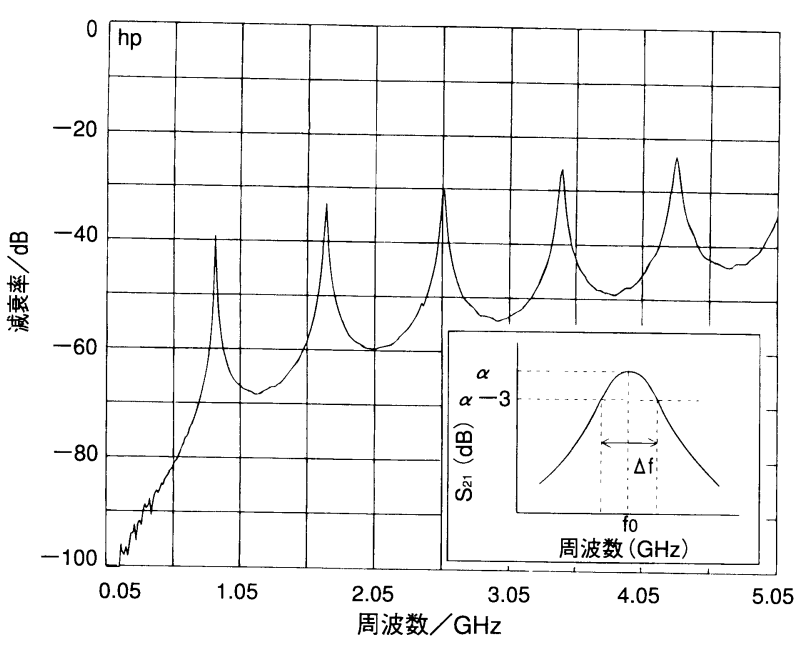

図 2.S4100積層板で構成したトリプレートストリップライン共振器 の共振特性

(挿入図は 1 つの共振ピークの頂上付近の拡大模式図) 


$$
\begin{aligned}
\varepsilon_{\mathrm{r}}= & \mathrm{m}^{2} \mathrm{c}^{2} / 4 \mathrm{~L}^{2} \mathrm{f}_{0}{ }^{2} \\
& \mathrm{c} \text {; 真空中の光速 } 3.0 \times 10^{8} \mathrm{~m} / \mathrm{s} \\
& \mathrm{m} \text {; 共振次数 } 1,2,3, \cdots \cdots
\end{aligned}
$$

誘電率, 誘電正接の温度依存性の測定は一 $20^{\circ} \mathrm{C}$ と $80^{\circ} \mathrm{C} の$ 間で行った。測定は試料をネットワークアナライザに接続 し， $\mathrm{f}_{0}$ と $\mathrm{Q}$ 值を観測しながら，試料をドライアイスで冷却 あるいはリボンヒータで加熱し, 試料に密着させた熱電対 で温度を調べることにより行った。

加湿条件下での誘電率, 誘電正接の安定性を評価するた めにプレッシャークッカー試験を実施した。加湿条件は $121^{\circ} \mathrm{C}, 2$ 気圧, 相対湿度 $100 \%$ とした。加湿は 6 時間行い, プレッシャークッカーから取り出した試料を $23^{\circ} \mathrm{C}$, 相対湿 度50\%の環境に 1 時間放置した後測定に用いた。加湿後の 試料については，はんだ耐熱試験も実施した。はんだ耐熱 試験の条件は $260^{\circ} \mathrm{C}, 120$ 秒とした。

伝送損失の測定は, トリプレート構造の特性インピーダ ンス $50 \Omega$ の伝送路を作成し，ネットワークアナライザで直 接に高周波信号の減衰量を調べることにより行った。試料 単位長さ当たりの減衰率を決定するにあたっては，コネク タの結合損失の影響を除くために伝送路長として $10 \mathrm{~cm}$ お び $5 \mathrm{~cm}$ の 2 種類の試料を用意し, 式（2）に従って求めた。

単位長さ当たりの減衰率

$=(10 \mathrm{~cm}$ 試料の損失 $-5 \mathrm{~cm}$ 試料の損失 $) /(10 \mathrm{~cm}-5 \mathrm{~cm})$

\section{2 試料}

熱硬化型PPE樹脂S4100積層板は，樹脂を有機溶剤によ りワニスとし，ガラスクロスに含浸，乾燥した後銅䇴と重 ね合わせて加熱プレスするという通常の銅張積層板製造プ ロセスにより作成した。ガラスクロスとしてはプリント配 線板に用いる際のドリル加工性を考慮し，FR-4銅張積層板 に一般的に用いられているEガラスクロスを使用した。

用いた各種試料の電気用銅張積層板としての一般的な特 性值を, 表 1 に示す。S4100積層板は, 誘電正接が 0.0017 〜0.0020とフッ素樹脂積層板の0.0010～0.0015に近い，き わめて良好な值を示している。 $\mathrm{Tg}=200^{\circ} \mathrm{C}$ は, FR-4の $\mathrm{Tg}$ $\left(160^{\circ} \mathrm{C}\right)$ を上回り，ポリイミド $\left(\mathrm{Tg}=250^{\circ} \mathrm{C}\right)$ に次ぐ良好 な值である。S4100は低誘電率, 低誘電正接と耐熱性を兼 ね備えたユニークな材料である。すべての試料の厚みは $0.8 \mathrm{~mm}$ とした。誘電率, 誘電正接の測定用試料は, 両面銅

表 1. 銅張積層板の特性值

\begin{tabular}{l|c|c|c}
\hline & $\mathrm{S} 4100$ & フッ素樹脂 & FR-4 \\
\hline 比誘電率 $(1 \mathrm{MHz})$ & $3.4 \sim 3.6$ & $2.5 \sim 2.7$ & $4.7 \sim 5.0$ \\
誘電正接 (1MHz) & $0.0017 \sim 0.0020$ & $0.001 \sim 0.0015$ & $0.015 \sim 0.019$ \\
ガラス転移温度 (DMA) & 200 & 25 & 160 \\
$\left({ }^{\circ} \mathrm{C}\right)$ & & & \\
銅箔引きはがし強さ & $1600 \sim 1800$ & 2200 & $1900 \sim 2300$ \\
$(\mathrm{~N} / \mathrm{m})$ & & & $\mathrm{V}-0$ \\
燃焼性 (UL94) & $\mathrm{V}-0$ & $\mathrm{~V}-0$ & \\
\hline
\end{tabular}

張積層板として入手したものを，エッチングにより銅䇴を 完全に取り除いて用いた。ストリップライン共振器のスト リップ導体は, 厚み $35 \mu \mathrm{m}$ の銅箔を必要な形状に切ったも のを積層板に貼り付けて形成した。伝送損失測定に使用し た試料は，形態を実際に使用される条件になるべく近づけ るために，伝送路をエッチングにより形成した。特性イン ピーダンスZ弪設計式 (3)，(4) ${ }^{4)}$ により行った。

$$
\begin{aligned}
& \mathrm{Z}_{0}=60 \sqrt{\varepsilon} / \log _{\mathrm{e}}(4 \mathrm{~b} / \pi \mathrm{d}) \\
& \mathrm{d}=(\mathrm{w} / 2) \cdot\left[1+(\mathrm{t} / \pi \mathrm{w}) \cdot\left(1+\log _{\mathrm{e}}(4 \pi \mathrm{w} / \mathrm{t})+0.51 \pi(\mathrm{t} / \mathrm{w})^{2}\right)\right] \\
& \text { ラメータ }
\end{aligned}
$$

\section{3 測定の精度}

誘電率の測定精度は測定時の試料の温度の安定度，共振 周波数の精度，ストリップ導体の長さLの精度，およびス トリップ導体の縁端効果の見積り精度により支配される。 誘電正接の測定精度に影響する因子は, 試料の温度の安定 度, ストリップ導体の厚み $\mathrm{t}$ の精度, 共振器の厚み $\mathrm{b}$ の精 度, および共振半值幅 $\left(\Delta \mathrm{f} / \mathrm{f}_{0}\right)$ の測定精度である。この うち, 共振半值幅は外部要因であるストリップライン共振 器の組み付け精度にも影響される。われわれの検討では， 本研究の測定における各要因の寄与の大きさは明らかでは ないが, 同一試料の繰り返し測定では比誘電率測定值のば らつきは土0.005程度, 誘電正接測定值のばらつきは誘電 正接が $10^{-3}$ オーダーの場合 $\pm 0.0005,10^{-2}$ オーダーの場 合士0.001程度である。測定精度についてわれわれは誘電 率標準試料の参照は行っていない。田中らはポリエチレン 試料の誘電率および誘電正接の值を空洞共振器の結果と比 較し, 損失分離法と空洞共振器法が同等の測定值を与える ことを確かめている゙๋。

伝送損失の測定精度は減衰率の精度により支配される。 HP8510Bの較正キットと較正ソフトウエアによる補正を施 した状態で, 減衰率は土0.1dB程度のばらつきを有する。 本研究では試料長を $10 \mathrm{~cm}$ および $5 \mathrm{~cm}$ としているので, 単位 長さ当たりの伝送損失は最も精度が良いときで土 $0.02 \mathrm{~dB} /$ $\mathrm{cm}$ 程度の幅を有する。

\section{3. 結果と考察}

エポキシ樹脂積層板（FR-4）, フッ素樹脂積層板（PTFE）, および熱硬化型PPE樹脂積層板（S4100）の常温における 比誘電率の周波数依存性の測定結果を図 3 に示す。同じく 誘電正接の常温における周波数依存性の測定結果を図 4 に 示す。比誘電率および誘電正接のいずれにおいても， S4100はFR-4より優れていることがわかる。S4100の比誘 


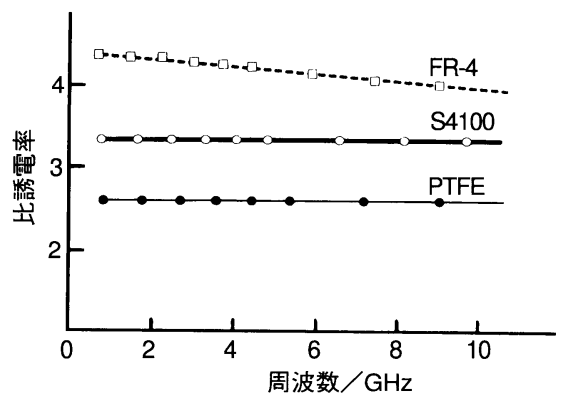

図 3. 23 C における比誘電率の周波数依存性

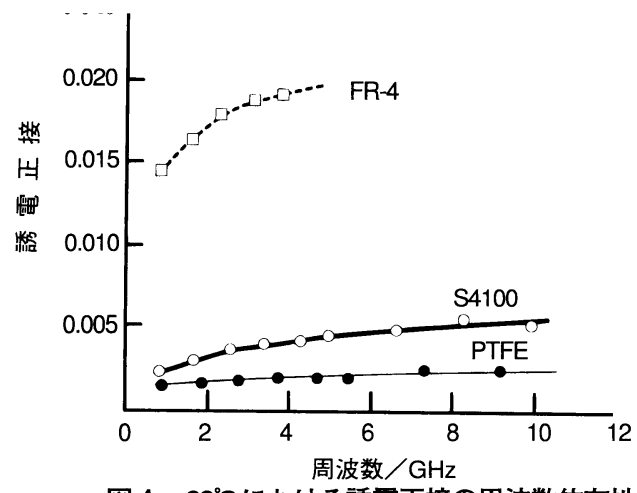

図 4. $23^{\circ} \mathrm{C}$ における誘電正接の周波数依存性

電率は $0.8 \sim 10 \mathrm{GHz}$ の周波数範囲でほぼ一定値を示してい る。FR-4はこの範囲で 0.3 程度比誘電率が変化する。つま りS4100は使用周波数が変わっても特性インピーダンスに 影響が出ないので，FR-4に比べ設計を共通化しやすいとい うメリットがある。S4100の誘電正接はPTFEに近い。周波 数依存性も比較的フラットであり，周波数変更時の設計へ の影響は小さいと考えられる。FR-4積層板で構成したス卜 リップライン共振器のQ值が $5 \mathrm{GHz}$ 以上の周波数では 50 を 下回るようになるため測定が困難になり，5 GHz以上の領 域のFR-4の誘電正接の正確な值は求められなかった。

$2 \mathrm{GHz}$ における各材料の誘電率および誘電正接の温度依 存性をそれぞれ図5 打よび図 6 に示す。本研究の測定温度 範囲ではS4100のみ, 比誘電率が不変であった。フッ素樹 脂積層板の誘電率の $20^{\circ} \mathrm{C}$ 付近における階段状の変化は, フ ッ素樹脂のガラス転移によるものである。温度特性が重要 な用途では，この急激な変化を十分に見込む必要があると 考えられる。この誘電率の階段状変化は, 小林らによるフ ッ素樹脂積層板の平衡形円板共振器による精密な複素誘電 率測定においてすでに見いだされているものと同様である5)。 FR-4の比誘電率の緩やかな変化は, エポキシ樹脂の熱膨張 に由来するものと考えられる。FR-4およびS4100のガラス 転移温度は，それぞれ $160^{\circ} \mathrm{C}$ 打よび200 220 ${ }^{\circ} \mathrm{C}$ なので，ガ ラス転移温度が測定温度範囲により近いFR-4の方に熱膨張 の影響が大きく現れたものと考えられる。誘電正接の温度 依存性は，フッ素樹脂積層板およびS4100積層板ではほと んどなく, FR-4積層板では明瞭である。FR-4積層板はもと もと誘電正接が大きい上, 温度依存性があるので, $2 \mathrm{GHz}$ 以上の周波数での使用には基本的に不向きであると考えら

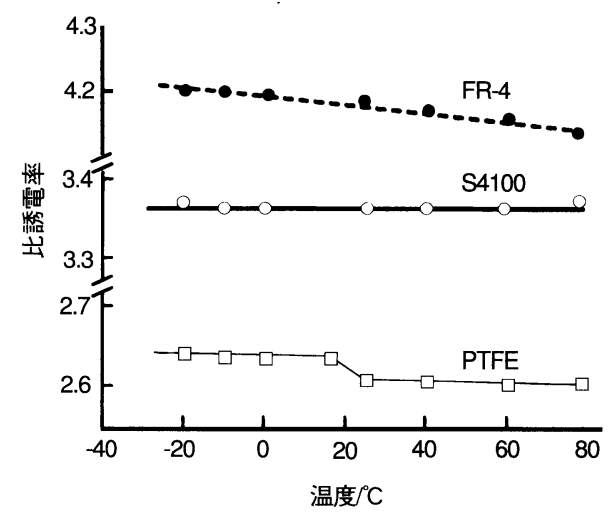

図 5. 比誘電率の温度依存性 $(2 \mathrm{GHz})$

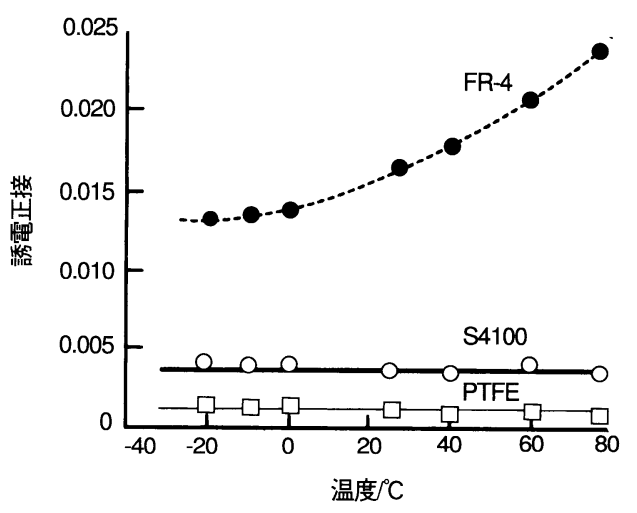

図 6. 誘電正接の温度依存性（2GHz）

れる。

$2 \mathrm{GHz}$ で測定したプレッシャークッカー試験前後の誘電 特性の変化, および吸湿後のはんだ耐熱試験の評価結果を 表 2 に示す。3 種類の材料を比較すると, FR-4積層板は最 も吸水率が大で, 誘電率, 誘電正接の変化も大きい。フッ 素樹脂積層板はこの試験条件では最も特性が安定してい る。S4100はわずかに誘電正接の増大が認められるが， $2 \mathrm{GHz}$ において $\varepsilon_{\mathrm{r}}=3.45, \tan \delta=0.0068$ は十分良好な值で あると考えられる。フッ素樹脂積層板に近い安定した特性 であると言える。プレッシャークッカー吸湿後のはんだ耐 熱試験では, FR-4にのみふくれが発生した。FR-4の吸水率 が0.9\%とS4100の0.2\%，PTFEの0.0\%に比べ大きいことが， 誘電特性にもはんだ耐熱性にも影響している。

図 7 に, 室温で測定した各材料の伝送損失の周波数依存

表 2.プレッシャークッカー試験前後の誘電特性の変化 $(2 \mathrm{GHz})$

測定温度 $; 23^{\circ} \mathrm{C}$

\begin{tabular}{|c|c|c|c|c|}
\hline & & S4100 & フッ素樹脂 & FR-4 \\
\hline \multirow[t]{2}{*}{ 比誘電率 } & 試験前 & 3.36 & 2.65 & 4.20 \\
\hline & 試験後 & 3.45 & 2.65 & 4.39 \\
\hline \multirow[t]{2}{*}{ 誘電正接 } & 試験前 & 0.0040 & 0.0013 & 0.0166 \\
\hline & 試験後 & 0.0068 & 0.0013 & 0.0277 \\
\hline 吸水率 & $\%$ & 0.2 & 0.0 & 0.9 \\
\hline \multicolumn{2}{|c|}{ 吸湿後はんだ耐熱性 } & & & \\
\hline \multicolumn{2}{|c|}{$260^{\circ} \mathrm{C} 、 120$ 秒 } & OK & $\mathrm{OK}$ & ふくれ発生 \\
\hline
\end{tabular}




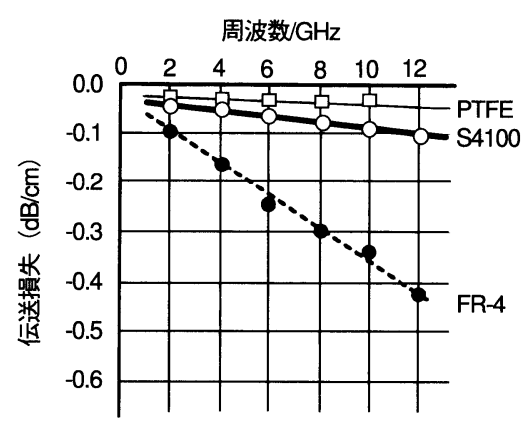

図 7. 伝送損失の周波数依存性

性を示す。測定精度の範囲内 $( \pm 0.02 \mathrm{~dB} / \mathrm{cm})$ で, $S 4100$ 積 層板の伝送損失は， $4 \mathrm{GHz}$ 程度まではフッ素樹脂積層板と 同等であると考えられる。 $\mathrm{S} 4100$ 積層板は $10 \mathrm{GHz}$ まで $0.1 \mathrm{~dB} / \mathrm{cm}$ 以下の低伝送損失であり, 高周波用プリント配線 板用として好ましい材料であることがわかった。

S4100積層板とフッ素樹脂積層板を比較した場合，特に 低い周波数側では各材料の誘電正接および誘電率の值の差 ほどには伝送損失の差は現れていない。著者らはプリント 回路上の信号の伝送損失 $\alpha_{\text {total }}$ は材料の誘電率の平方根と誘 電正接の積に比例する誘電体損失 $\alpha_{\text {dielectric }}$ が主であると考え ていたが，表 2 に示した $2 \mathrm{GHz}$ におけるS4100とPTFEの比 誘電率および誘電正接の值を用いると，S4100積層板の損 失はPTFE積層板の損失の 3.5 倍と計算されるので，この考 えでは実測值を説明しにくい。プリント回路のもう一方の 損失要因である導体損失 $\alpha_{\text {conductor }}$ 無視できるほどには小さ くないと推定される。式（5），(6)，(7) に示すとおり誘 電体損失は周波数に比例し，導体損失は周波数の平方根に 比例することが知られている ${ }^{4)}$ 。実測値の低周波側で，導 体損失の寄与が比較的大きく見られることと定性的に一致 する。これらのことから，低損失材料については，材料の 誘電率, 誘電正接を知るだけでは損失挙動の推定を完全に 行うことはできないと考えられる。損失測定を精度良く行 い，かつ環境に対する安定性の評価を実施して，実際の高 周波回路における信号損失挙動の安定性を材料の特性值か ら定量的に議論することが, 絶縁信頼性の観点からも今後 必要になると考えられる。

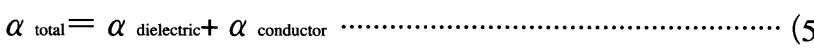

$$
\begin{aligned}
& \alpha_{\text {dielectric }}=27.3 \cdot \mathrm{f} \cdot \sqrt{\varepsilon} \cdot \tan \delta / \mathrm{c} \\
& \alpha_{\text {condutuor }}=\frac{2.02 \times 10^{-6} \cdot \sqrt{\varepsilon} \cdot \sqrt{\mathrm{f} \cdot} \cdot \mathrm{z}}{\mathrm{b}} \cdot\left[\frac{1}{1-\mathrm{t} / \mathrm{b}}+\frac{2 \mathrm{w} / \mathrm{b}}{(1-\mathrm{t} / \mathrm{b})^{2}}+\frac{1+\mathrm{t} / \mathrm{b}}{\pi(1-\mathrm{t} / \mathrm{b})^{2}} \log _{\mathrm{e}}\left(\frac{\frac{1}{1-\mathrm{t} / \mathrm{b}}+1}{\left.\frac{1}{1-t / b}-1\right)}\right]\right.
\end{aligned}
$$

\author{
$\mathrm{f}$; 周波数 $(\mathrm{Hz})$ \\ c ; 真空中の光速 $(\mathrm{cm} / \mathrm{s}$; 損失を $\mathrm{dB} / \mathrm{cm}$ で表示す \\ る場合） \\ $\mathrm{Z}$ ；スドリップラインの特性インピーダンス $(50 \Omega)$ \\ (他の記号は図 1 と同じ)
}

\section{4. 結論}

高耐熱性，かつ良好な誘電特性を有する熱硬化型PPE樹 脂S4100を開発した。S4100の積層板について $0.8 \sim 10 \mathrm{GHz}$ における誘電率, 誘電正接を測定し, それらの温度および 湿度に対する安定性を評価した。FR-4積層板，フッ素樹脂 積層板と比較したところ, S4100積層板はフッ素樹脂積層 板に近い性能，および安定性を有することが確認された。 伝送損失を測定したところ, S4100積層板は，4 GHz程度 までフッ素樹脂積層板に匹敵する低伝送損失であることが わかった。

\section{謝辞}

本研究における高周波測定の治具を設計し，測定全般を 実施した樋山豊一氏（旭化成工業）に感謝いたします。

(1994.12.8－受理１995.1.23－再受理)

\section{文献}

1) Hiroji Oda, Takeshi Arai, Haruhisa Sasaki, Teruo Katayose: "Unique Allylated Polyphenylene Ether for Low Dielectric Printed Circuit Boards", Proceeding of Printed Circuit World Convention VI, T6-1 (1993)

2）新井雄史, 小田弘治, 片寄照雄：“低誘電率プリント配線 板用アリル化ポリフェニレンエーテル”, サーキットテクノ ロジ, 9 (6)，429(1994)

3) Hiroyuki Tanaka and Fumiaki Okada : "Precise Measurements of Dissipation Factor in Microwave Printed Circuit Boards", IEEE Transaction on Instrumentation and Measurement, 38 (2) , 509 (1989)

4) Harlan Howe, Jr. : “Stripline Circuit Design”, Chapter 1, Artech House (1974)

5）小林禧夫, 于 静：“平衡形円板共振器による複素誘電率 の自動測定”，電子情報通信学会技報マイクロ波MW91-17， 5 月, (1991) 